\title{
Effect of Thermal Pretreatment on the Yield of Biogas from Microcoleous Vaginatus
}

\author{
M. Haruna ${ }^{1}$, O. R. Momoh², S. Bilal ${ }^{2}$ \\ ${ }^{1}$ Department of Chemical Engineering, Federal Polytechnic, Bida, Nigeria. \\ ${ }^{2}$ Department of Chemical Engineering, Ahmadu Bello University, Zaria, Nigeria.
}

\begin{abstract}
Biomass is being looked upon as one of the promising renewable energy sources for the future, with growing interest in microalgae conversion into biogas through anaerobic digestion. Recently, the ability of microalgae to treat waste water has doubled its potentials material today. However, in spite of the progress made in that regards, there are still challenges of algae conversion to biofuel, due to the presence of complex cell wall in some algae. Cell wall inhibits bacteria growth during degradation. In this research work 10 grams of Microcoleous vaginatus was treated in an oven at varying temperatures of 70,75 and $80{ }^{\circ} \mathrm{C}$ for an hour, out of which $4 \mathrm{~g}$ was measured into 250 $\mathrm{ml}$ serum bottle for digestion at mesophilic temperature of $37{ }^{\circ} \mathrm{C}$. Based on the results of proximate analysis, $69 \%$ increase in carbohydrate was attained with $72.7-148 \%$ reduction in moisture content. The biogas yield of untreated sample was $4.36 \mathrm{mLg}^{-1} \mathrm{VS}$, while, pretreated samples at 70,75 and $80{ }^{\circ} \mathrm{C}$ produced $8.39,9.07$ and $9.38 \mathrm{mLg}^{-1} \mathrm{VS}$ (volatile solid) of biogas. This corresponds to 92, 108 and 115\% higher than that of untreated samples. However, thermal treatment of $M$. vaginatus prior to digestion show positive effect on carbohydrate extraction and enhanced biogas and methane yield as well. Therefore, this makes the substrate a good feedstock for biogas production.
\end{abstract}

KEYWORDS: Biomass, pretreatment, thermal, anaerobic digestion, degradation, Microcoleous vaginatus.

[Received October 3, 2018, Revised March 3, 2019, Accepted April 6, 2019]

Print ISSN: 0189-9546 | Online ISSN: 2437-2110

\section{INTRODUCTION}

Environmental degradation caused by fossil fuels on human habitat and life had necessitated the need for alternative sources of energy that will be ecofriendly and cost effective. In that regards many research interest have been drawn to renewable energy sources (Chen et al., 2011). Though, it is apparent that urgent need for alternative as well as cheaper sources of energy in developing countries of the world is long overdue, due to hardship posed by militancy, piracy and corruption on fossil facilities. On that note many rural community are forced to use wood as a major source of energy. But, cost, scarcity and government regulations on the wood resources had make access to wood difficult as well. According to Ukono (2011) between 1999 and 2011 the price of petroleum products had skyrocketed to more than $120 \%$ where several efforts by the government to restore normalcy in that sector have not made any appreciable impact, as fuel prices are rising on daily basis.

However, harnessing other forms of energy obtainable from Sun, Wind, Waves, Tidal, Geothermal or Biofuels will go a long way in reducing if not solving the problems of fossils completely. Phunkan et al., (2011) found the use of biofuel over other alternatives more recommendable due to its low capital and technological requirement during establishment. Chen et. al., (2009) found promising potential in microalgae when used for biofuel production since it is known for high yield of biogas, low competition with food for arable land during cultivation and can be grown on land even unfit for cultivation. These potentials traced to microalgae brought about research interest to microalgae species with large

*Corresponding author: mtharuna05@gmail.com amounts of metabolites to improve bioethanol, biodesiel or biogas production (Dragone et al., 2010).

Currently, the quantity of materials used for biogas production is limited. It then calls for new substrates and effective technology to facilitate growth in biogas industry (Horváth et al., 2016). This is more pronounced in developing countries of the world, where consumer's demands are yet to be met. (Aminu et al., 2013). Energy is known as one of the bedrock for socio-economic development of every society. Chisti (2007) stressed the need for microalgae conversion to energy because of its potentials of rapid growth in water bodies, $\mathrm{CO}_{2}$ bio-fixation (main carbon source for growth), low water demand for cultivation, no competition with food production, can be grown in different environments, the required nutrients for growth may be obtained from environment unfit for normal cultivation such as wastewaters, they have high oil content (20-25\% dry matter), they can be used as food or fertilizers and its biochemical composition can be modulated by different growth conditions (Chisti, 2007; Sheehan et al., 1998, Schenk et al., 2008; Phukan et al., 2011; Lakaniemi et al., 2011).

Passos et al., 2014 studied the influence of thermal and chemical pretreatment on microalgae conversion to bioenergy and revealed that, thermal and chemical pretreatment of microalgae biomass gave an improved digestion and bioenergy as well. Andrés et al., (2014) studied the effect of thermal pretreatment on fermentable sugar production of Chlorella Vulgaris. In another work, Passos et al., (2015) compared different pretreatment methods of thermal, hydrothermal, microwave and ultrasound to improve microalgae digestion. The results showed that, organic matter solubilisation was 
higher for thermal pretreatment (20 - fold) when compared to hydrothermal ( 9 - fold), microwave ( 8 - fold) and ultrasound (7 - fold) pretreatments

These derived benefits from microalgae gave it the status "environmental friendly" for large-scale production of biogas. But, it is imparative to understand the physical and chemical properties of the species involved, since it is one of the critical tools, to the development of an appropriate process for a large scale production. Meanwhile, this work seeks to utilize Microcoleus vaginatus as a feedstock for fermentative anaerobic digestion, through critical study of thermal pretreatments for the enhancement of biogas production. The relative ease at which this algae specie can be identified, its abundance in biocrust and diverse method of its isolation and cultivation makes it a preferred choice for this study.

\section{MATERIALS AND METHODS}

\section{A. Materials}

The strain of $M$. vaginatus used was obtained from River Landzun in Bida Local Government Area of Niger State, Nigeria. Glass capillary tube was used for isolation and gently transferred into sterile water for serial dilution. The isolated strain was cultured at the Unit Operation Laboratory, Chemical Engineering Department, Federal Polytechnic, Bida. The culturing medium was set as the natural algae habitats because of its sensitivity to physiological conditions of temperature, $\mathrm{pH}$ and salinity Ogbonna, (2011). Each cultured medium was grown for 14 days before it was harvested through filtration on filter cloth and then sun dried for 3 days. The dried samples were kept in an air tight polythene bags before the subsequent stage. The dried sample was crushed using mortar and pestle then screened using Endecott test sieve mounted on sieve shaker. The particles collected on $600 \mu \mathrm{m}$ mesh size were used for pre-treatment before digestion.

\section{B. Thermal Pretreatment Process}

The thermal pretreatment was conducted in an oven at constant time of 1 hour and varying temperature of 70,75 and $80^{\circ} \mathrm{C}$. Eight grams each of $M$. vaginatus was measured on to metallic containers labelled A1, A2, and A3 then placed in the oven for an hour each at varying temperature. The samples were then removed from the oven and transferred into three digesters for onward digestion as described by Passos et al., (2013).

\section{Anaerobic Digestion}

A batch process of anaerobic digestion was adopted in $250 \mathrm{ml}$ plastic bottle with the slurry temperature maintained at $37^{\circ} \mathrm{C}$ in a water bath. Four grams each of pretreated samples was measured into $250 \mathrm{ml}$ digester. Then, $2 \mathrm{~g}$ of fresh cow dung thoroughly mixed with $10 \mathrm{ml}$ of deionized water was then was poured into each digester. In order to provide substrate to liquid ratio of 1:10, another $50 \mathrm{ml}$ of deionized water was added to each digester and the remaining headspace in the digester was for the gas generated. Digesters $\mathrm{C}$ was charged with $4 \mathrm{~g}$ of untreated $M$. Veginatus, $2 \mathrm{~g}$ of cow dung and $60 \mathrm{ml}$ of deionized water, while the reference sample B was charged with $2 \mathrm{~g}$ of cow dung and $60 \mathrm{ml}$ of water.

The digester sample was made in duplicate and thoroughly shaken to provide homogenous slurry (Murphy et al., 2014). The deionised water added was added to dissolve substrate and to provide conditions favourable for microorganisms that fed on the substrate. The digesters were properly sealed with adhesive gum to obtain an air free environment (Poole et al., 2014). Proximate, Ultimate, and Scanning Electron Microscope analyses were conducted before, and after pre-treatment on dry basis. The $\mathrm{pH}$ and ambient temperature were measured daily. While, daily gas productions were measured through inverted cylinder and the duplicate samples collected in gas bags were analysed with gas sampler connected to a gas chromatography unit.

The proximate composition of $M$. vaginatus was determined according to AOAC methods (AOAC, 1990). For the moisture content the sample was allowed to stay in an oven at $100-105{ }^{\circ} \mathrm{C}$ for $6-12 \mathrm{hrs}$ until a constant weight was obtained. Then, the crucible was placed in a desiccator for 30 mins to cool. The ash was determined after putting the sample in a crucible and placed over a burner until it charred. Then, the crucible was placed in muffle furnace for ashing at $550{ }^{\circ} \mathrm{C}$ for $2-4 \mathrm{~h}$. Appearance of gray white ashing indicates complete oxidation of all organic matter in the sample. Crude protein content was measured by a standard Kjeldahl method using 5.95 as the conversion factor. The content of lipids in $M$. vaginatus was analysed by the solvent extraction procedure. Total carbohydrates were determined by the difference of all the proximate values. The complete flow process is illustrated in Figure 1.

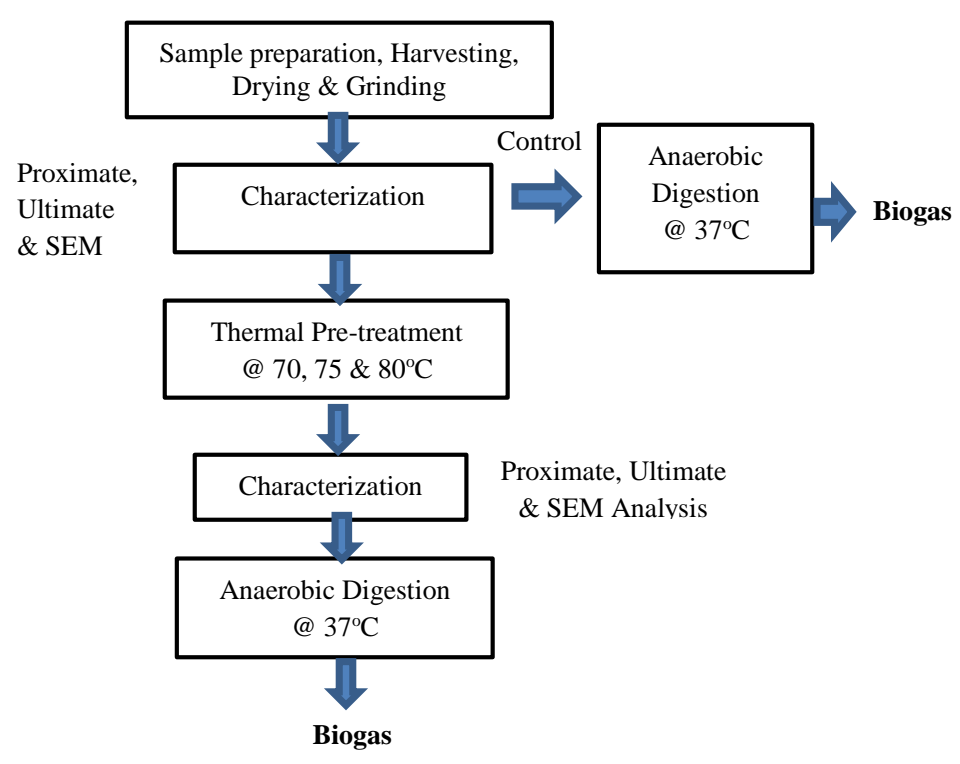

Figure 1: Process flow diagram. 


\section{RESULTS AND DISCUSSION}

\section{A. Characterization of Substrate Biomass}

The nutrients and morphological analysis of treated and untreated M. vaginatus was carried out through Proximate, Ultimate and SEM analysis of the samples. Likewise, biogas produced was characterized and microbial counts of the slurry digestate before and after the digestion were also observed. Figure 2 reveals the nutritional properties of the substrate. Properties such as fat, ash, moisture, protein, crude fibre and carbohydrate were determined and shown.

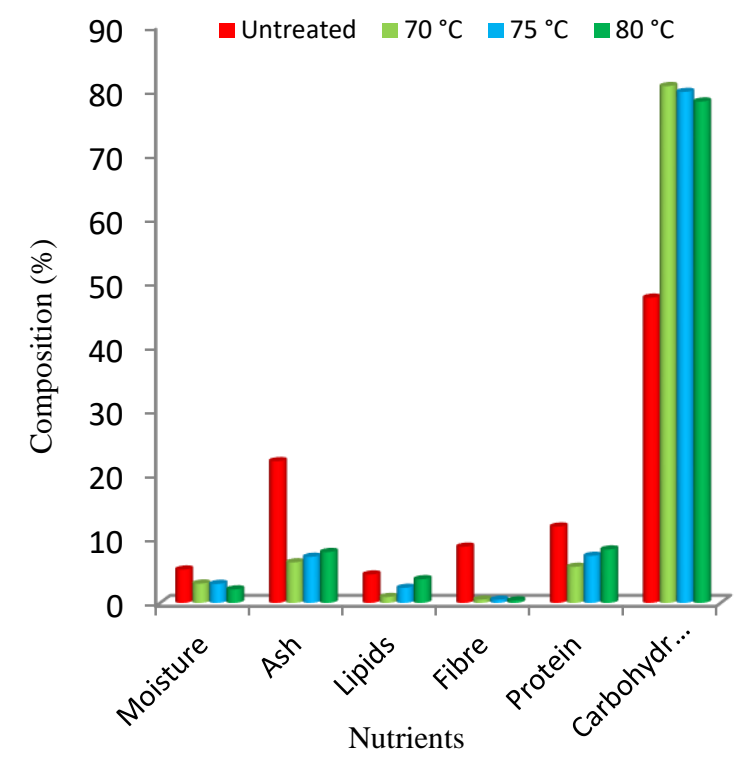

Figure 2: Proximate analysis of $M$. vaginatus before and after thermal pretreatment.

The proximate analysis revealed that, $M$ vaginatus contain $5.2 \%$ moisture, $22.1 \%$ ash, $4.47 \%$ lipids, $8.76 \%$ crude fibre, $11.9 \%$ protein and $47.6 \%$ carbohydrate. The pretreatment at 70,75 and $80{ }^{\circ} \mathrm{C}$ has increased the carbohydrate extraction to between $72.2-80.6 \%$ and gave rise to $69.3 \%$ improvement over control sample. Miranda et al., (2012) reported that variation in biomass concentration can result in variation in the amount of sugar that will be released. The water removed by the microspores of the cellulose in the algae cell wall brought about irreversible changes in the structure to form amorphous area in which the voidage between the elasticity is reduced making the fibre more susceptible to attack by acids that was formed during the digestion process.

The substrate moisture content was reduced from 5.2 to $3.01 \%, 2.96$, and $2.10 \%$ at 70,75 and $80{ }^{\circ} \mathrm{C}$ respectively. This implies that, raise in temperature increases the rate at which the moisture can be removed from the sample as evidenced with the findings of (Silva et al., 2008; Zou et al., 2010; \& Chen et al., 2011). Anaerobic digestion requires a certain level of moisture in feedstock for efficient substrate conversion as large-scale production requires 8 to $10 \% \mathrm{wt}$ moisture in the feedstock. The ash content of all the treated samples were reduced from $22.1 \%$ to $7.32,7.20$ and 7.18 at 70,75 and $80^{\circ} \mathrm{C}$, respectively. According to $\mathrm{Bi} \& \mathrm{He}$ (2013) green microalgae with low ash content of less than $10 \%$ is preferred to brown or mixed brown microalgae with high ash content of $43 \%$ wt; high level of ash have negative effect when processed for biofuels. Some microalgae species have high level of lipids and, that is why they are used for bio-diesel production (this is not as clumsy as what is there before). High level of lipids in some microalgae species gave rise to the advantage of being used in biodiesel production. Ultimate analysis gives report of elemental composition of the substrate used, elements such as carbon, hydrogen, nitrogen, sulphur and oxygen were determined.

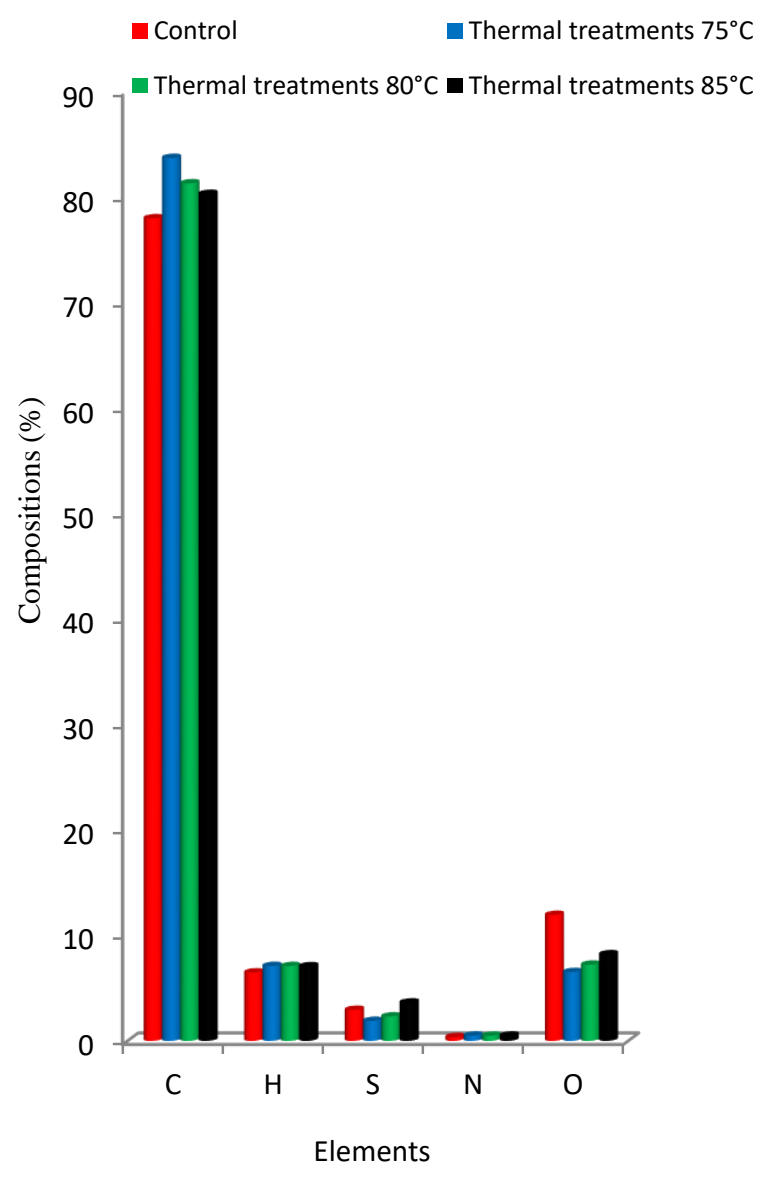

Figure 3: Ultimate analysis of thermal pretreated samples.

Figure 3 revealed that raw sample contains $77 \%$ carbon, $6.58 \%$ hydrogen, $2.98 \%$ sulphur, $1.36 \%$ nitrogen and $12.08 \%$ oxygen. The carbon content for thermally treated samples were enhanced from $77 \%$ to $82.7,83.1$ and $83.3 \%$ at 70,75 and $80{ }^{\circ} \mathrm{C}$ respectively. This increase was due to the fact that, temperature can reduce the binding forces of lignin to release simple sugar from the substrate used. The increase in carbon corresponds with the one noticed in carbohydrate (starch and cellulose) through proximate analysis. The carbohydrate primarily comprised of carbon, hydrogen and oxygen. According to Bi and $\mathrm{He}$ (2013) carbon content in biomass correlates proportionally to the heating value of the expected biofuel from the substrate.

Also shown in Figure 3 is that hydrogen was $6.58 \%$ before pretreatment, this was close to $7.1 \%$ hydrogen found in Chlorella vulgaris as reported by $\mathrm{Bi}$ and $\mathrm{He}$ (2013). It was then increase to $7.21,7.20$ and $7.18 \%$ after treatment at 70,75 and $80{ }^{\circ} \mathrm{C}$. An indication that, increase in temperature caused a 
decrease in hydrogen content. Nielfa and Cano (2015) reported that, substrates with high hydrogen and nitrogen content promotes toxic concentration of ammonia and hydrogen sulphide in the digester. The initial content of sulphur was 2.98 $\%$ then reduced to $1.92 \%$ at lower pretreament temperature of $70{ }^{\circ} \mathrm{C}$, and as the pretreatment temperature increases there was an increase to $2.35 \%$ and $3.69 \%$ at 75 and $80{ }^{\circ} \mathrm{C}$.

High protein content in anaerobic substrates implied high nitrogen content that was not desirable in biogas production. However, low nitrogen and sulphur is more desirable for environmental friendly biofuels (Bi and $\mathrm{He}, 2013)$. Untreated sample of $M$. vaginatus had $1.36 \%$ nitrogen and increase with pretreatment temperature to $1.51 \%, 2.32 \%$ and $2.87 \%$ at 70 ${ }^{\circ} \mathrm{C}, 75^{\circ} \mathrm{C}$ and $80^{\circ} \mathrm{C}$ respectively. This increase in nitrogen after pretreatment was beneficial in stabilizing $\mathrm{C}: \mathrm{N}$ ratio during digestion. According to Jard et al., (2013) optimum levels of C:N ratio for biogas production are in the range of 20:1 to 30:1. While, enzymatic activities on nitrogenous substrates with C:N ratio less than 15 can cause formation of ammonia in the digester thereby raise the level of ammonia in digester system to cause microbial inhibition (Allen et al., 2013). Protein is the primary source of nitrogen concentrations and is low in brown seaweeds but, high in red and green seaweeds (Jard et al., 2013). Thus, it is therefore better to use either red or green sea weed for efficient biogas production.

Usually, oxygen affect heating value in an inverse manner, an indication that high amount of oxygen is not desirable when biofuels with higher energy density is required. Anaerobic digestion is a complex process that involves biochemical reaction by several types of microorganisms that requires no oxygen to survive. The oxygen inhibits the methanogens which convert other intermediate compounds formed into methane. Therefore, it is essential to maintain an oxygen reduced or free environment for an enhanced methanogenic growth.

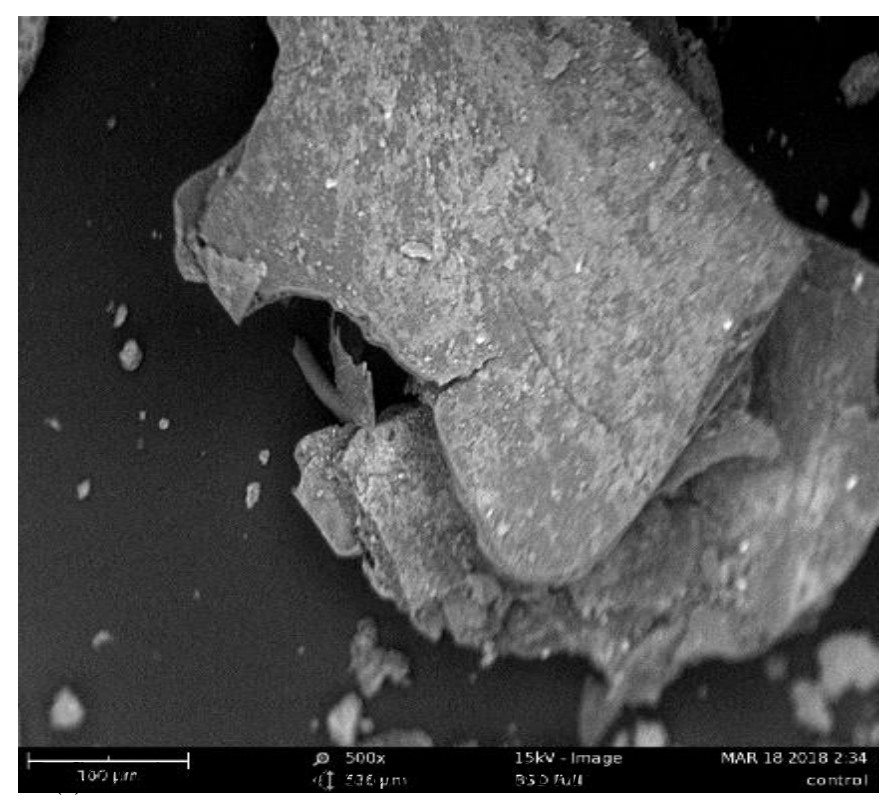

(a)
SEM analysis uses a focused beam of high energy electron to generate signal at the surface of solid particle. The carbohydrate which housed the cellulose and hemicellulose are decomposed from lignin by thermal pretreatments and resulted into substrate weaken and inter wall cracks provide an improved biomass degradation. Therefore, in order to ascertained this thermal effect on the samples, SEM analysis of the minimum and maximum pre-treatment temperature was conducted to compare the effect on composition and substrate morphology before and after pretreatment as shown in Figure 4.

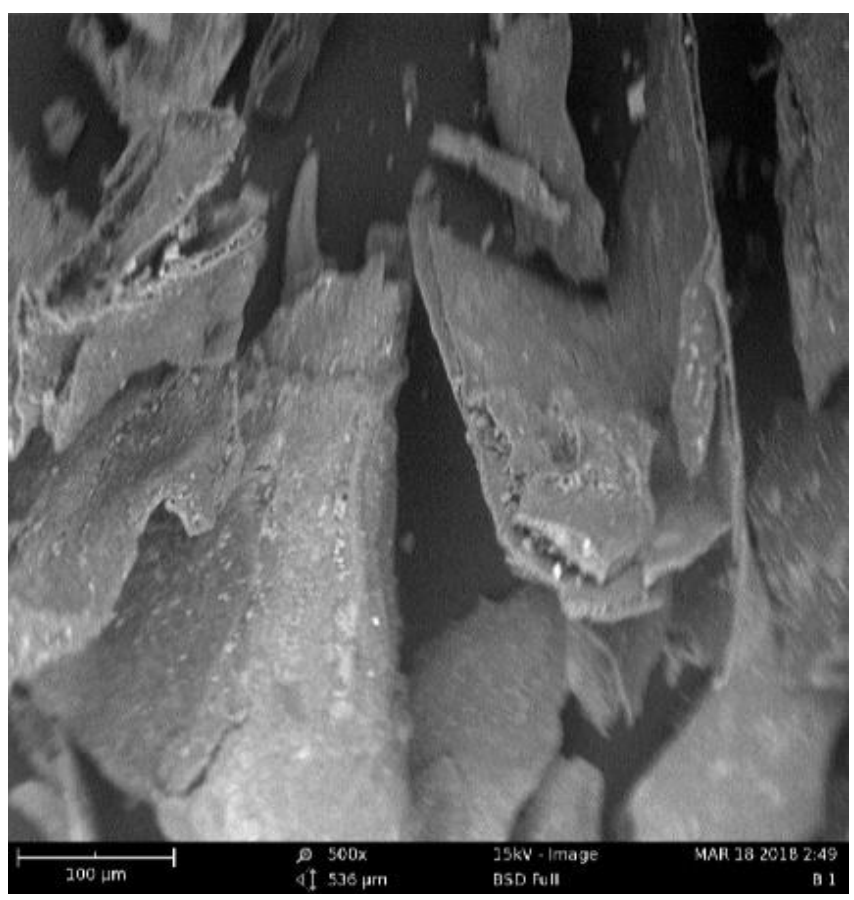

(b)

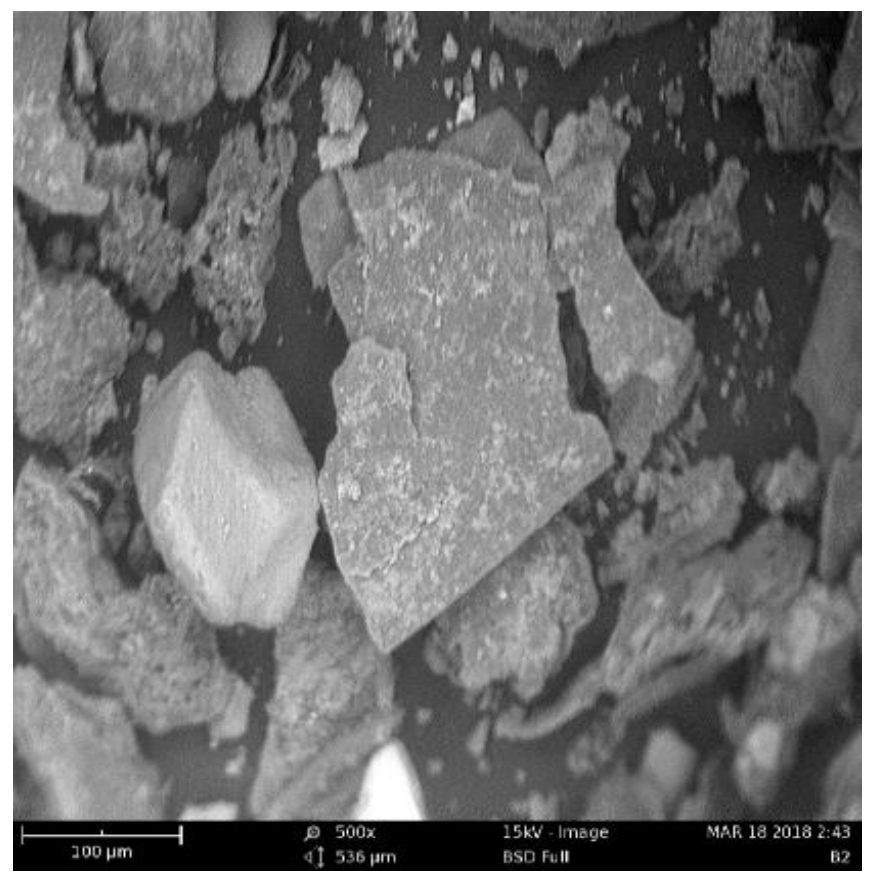

(c) 
Figure 4 shows the SEM visualization of thermally treated M. vaginatus. The images revealed that thermal treatment had significant effect on the nutrients and cell morphology of the substrate. The structural distortion at $80{ }^{\circ} \mathrm{C}$ was more evident over that of $70^{\circ} \mathrm{C}$ as observed. The images were taken at $100 \times$ magnification for all samples. There were significant structural changes observed after each pretreatment process than untreated, with more dispersion observed on sample pre-treated at $80{ }^{\circ} \mathrm{C}$. The cells structures of control sample remained intact, since the lignin effect in binding cellulose and hemicellulose together were still effective. While in contrary, increase in pretreatment temperature lead to an increase in cell disrupted resulted into a wider pore sizes. According to Cooney et al., (2011) temperature destroyed surface crystalinity to form amorphous material. It therefore, suggests that the pretreatment temperatures used on $M$. vaginatus had significantly affected the cell structure since more disintegration are observed as temperature increases between $70{ }^{\circ} \mathrm{C}$ and $80{ }^{\circ} \mathrm{C}$. Therefore, it is worth of note that treatment at $80{ }^{\circ} \mathrm{C}$ shown more tendencies for breaking the glycosidic bond in cellulose, hemicellulose and lignin to allowed bacteria access to the nutrient contained in the substrate via wall pores.

\section{Biogas Yield}

From Figure 5, the biogas yield of untreated sample was $4.36 \mathrm{mLg}^{-1}$ VS. The pretreated samples at 70,75 and $80{ }^{\circ} \mathrm{C}$ resulted in biogas yields of $8.39 \mathrm{mLg}^{-1} \mathrm{VS}(92 \%), 9.07 \mathrm{mLg}^{-1}$ VS $(108 \%)$ and $9.38 \mathrm{mLg}^{-1} \mathrm{VS}(115 \%$ higher than untreated) respectively. More than $5 \mathrm{~mL}$ of biogas produced for all the treated samples was in the first 10 days of digestion, while, the remaining were obtained in the remaining period of retention. Thermally treated sample at $80{ }^{\circ} \mathrm{C}$ produced biogas with a higher methane $\left(\mathrm{CH}_{4}\right)$ content. The $\mathrm{CH}_{4}$ content of the biogas from digestion of the untreated microalgae was $44 \%$, which was similar to the study conducted by Wang et al., 2013.

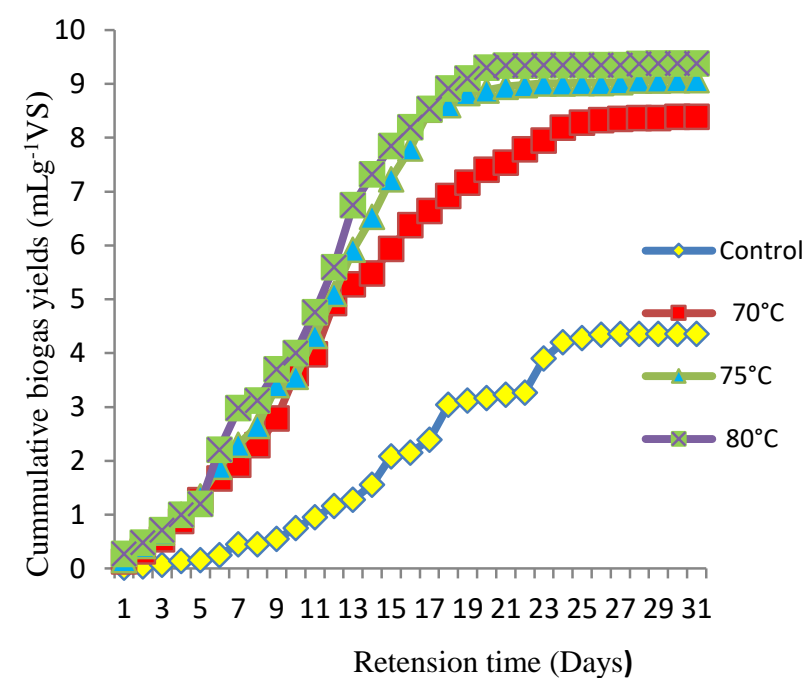

Figure 5: Biogas yield from untreated and thermal pretreated $M$. vaginatus.

\section{Biogas Characterization}

Biogas obtained after fermentation is usually a mixture of gases among which methane $\left(\mathrm{CH}_{4}\right)$ is more useful as energy sources. Generally, biogas consist $55-80 \%$ methane and 20 $45 \%$ carbon dioxide $\left(\mathrm{CO}_{2}\right)$, with other gases such as hydrogen sulfide $\left(\mathrm{H}_{2} \mathrm{~S}\right) \quad 0-3 \%$ and $0-1 \%$ hydrogen, nitrogen and ammonia. However, depends on the substrate type and processs management involved of the organic matter and the management of the anaerobic digestion process, small amounts of other gases such as ammonia $\left(\mathrm{NH}_{3}\right)$, hydrogen sulfide $\left(\mathrm{H}_{2} \mathrm{~S}\right)$ and water vapour $\left(\mathrm{H}_{2} \mathrm{O}\right)$.

Table 1: Characterization of biogas produced from M. vaginatus.

\begin{tabular}{lccccc}
\hline S/N & Compositions & Control & \multicolumn{4}{c}{ Pretreatment temperatures $\left({ }^{\circ} \mathbf{C}\right)$} \\
& & & 70 & 75 & 80 \\
\hline 1. & $\mathrm{CO}_{2}$ & 39.72 & 27.90 & 21.48 & 14.72 \\
2. & $\mathrm{CH}_{4}$ & 19.34 & 65.80 & 71.90 & 79.81 \\
3. & $\mathrm{H}_{2}$ & 14.83 & 3.05 & 2.92 & 1.23 \\
4. & Others & 26.11 & 3.25 & 3.70 & 4.24 \\
\hline
\end{tabular}

Table 1 revealed that, sample treated at $80{ }^{\circ} \mathrm{C}$ produced the highest volume of methane $79.81 \% \mathrm{CH} 4$, and this was followed by $71.9 \%$ and $65.8 \% \mathrm{CH}_{4}$ for $75{ }^{\circ} \mathrm{C}$ and $70{ }^{\circ} \mathrm{C}$, respectively.

\section{CONCLUSION}

In this work, 10 grams of Microcoleous vaginatus was treated in an oven at varying temperatures of 70,75 and $80{ }^{\circ} \mathrm{C}$ for an hour. Of this, $4 \mathrm{~g}$ was measured into $250 \mathrm{ml}$ serum bottle for digestion at mesophilic temperature of $37{ }^{\circ} \mathrm{C}$. The following conclusions were made;

(i.) Thermal pretreated M. vaginatus showed positive effect on carbohydrate extraction and it was observed that an increase in temperature resulted in enhanced extraction.

(ii.) Hydrolysis during substrate biodegradation was also eased and enhanced, leading to increased biogas yield. The highest value of biogas was obtained at 80 ${ }^{\circ} \mathrm{C}$ with methane production rate of $73 \mathrm{~mL} / \mathrm{VS}$. The biogas produced has an average methane content of $70.25 \% \mathrm{~mol}$.

(iii.)If the potentials of algea biogas is properly harnessed, it could serve as a viable option to other sources of energy such as petrol, coal and natural gas can be found.

(iv.) The use of $M$. vaginatus for biogas production contribute to sustainable development as algae cultivation required almost equal volume of $\mathrm{CO}_{2}$ emitted during combustion for its growth. The digestate obtained after digestion should be used for algae cultivation to reduce nitrogen formation during dig estion. Blend or co-digestion of $M$. vaginatus with other carbon rich material can also be helpful.

\section{REFERENCES}

Abdelmohsen, A., and Mohamed, M. (2016). Biological tools to improve Biogas production from microalgae biomass. PhD dissertation. pp. $16-23$ 
Allen, E.; J. D. Browne and J. D. Murphy. (2013). Evaluation of the biomethane yield from anaerobic codigestion of nitrogenous substrates. Environmental technology, 34(13-14), pp. 2059-2068.

Aminu, N. M.; N. U. Tijjani and Y. Y. Aladire. (2013). Overview of Biodiesel Production from Algae in Nigeria and Some Developing Countries. International Journal of Scientific \& Engineering Research, 4(1).AOAC (1990).Official Methods of Analysis: Association of Analytical Chemists. 14th Ed., Washington, USA, 22209.

Belnap, J. (1995). Surface disturbances: their role in accelerating desertification. Environ. Monitor. Assess. 37: pp. 39-57.

Bi, Z., and He, B. B. (2013). Characterization of microalgae for the purpose of biofuel production, 56(4), pp. 1529-1539.

Chen, C.; K. Yeh, R. Aisyah, D. Lee and J. Chang. (2011). Bioresource Technology Cultivation, photobioreactor design and harvesting of microalgae for biodiesel production : A critical review. Bioresource Technology, 102(1), pp. 71-81.

Chen, P.; M. Min; Y. Chen; L. Wang; Y. Li; Q. Chen; C. Wang; Y. Wan; X. Wang; Y. Cheng; S. Deng; K. Hennessy; X. Lin; Y. Liu; Y. Wang; B. Martinez and R. Ruan. (2009). Review of biological and engineering aspects of algae to fuels approach. International Journal of Agricultural and Biological Engineering 2 (4), pp. 1-30.

Chisti, Y. (2007). Biodiesel from microalgae. Biotechnology advances, 25(3), 294-306.

Cooney, M.; G. Young and R. Pate. (2011). Bio-oil from photosynthetic microalgae: Case study. Bioresource Tech. 102(1): pp. 166-177.

Craggs, R.J.; S. Heubeck; T.J. Lundquist and J.R. Benemann. (2011). Algae biofuel from wastewater treatment high rate algal ponds. Water Science and Technology, 63 (4), 660-665.

Dragone, G.; B. Fernandes; A.A. Vicente and J.A. Teixeira. (2010). Third generation biofuels from microalgae, 1355-1366.

Fulbright, S. P.; A. Robbins-pianka, D. Berg-lyons, R. Knight, K. F. Reardon and S. T. Chisholm. (2018). Bacterial community changes in an industrial algae production system. Algal Research, 31(6), pp. 147-156.

Garcia J.; R. Mujeriego and M. Hernádez-Mariné. (2000). High rate algal pond operating strategies for urban wastewater nitrogen. J Appl Phycol, 12, pp. 331-339.

Horváth, I. S.; M. Tabatabaei, K. Karimi and R. Kumar. (2016). Recent updates on biogas production - a review. Biofuel Resource Journal, 10, pp. 394-402.

Jard G.; H. Marfaing, H. Carrère, J. P. Delgenes, J. P. Steyer and C. Dumas. (2013). French Brittany macroalgae screening: Composition and methane potential for potential alternative sources of energy and products. Bioresource Technology. pp. 7-19

Krassig, H. and J. Schurz (2002): Ullmann's Encyclopedia of Industrial Chemistry, Sixth edition, Weinheim, Germany, Wiley-VCH.

Lakaniemi, A. M.; C. J. Hulatt; D. N. Thomas;
O. H. Tuovinen and J. A. Puhakka. (2011). Biogenic hydrogen and methane production from Chlorella vulgaris and Dunaliella tertiolecta biomass. Biotechnology for biofuels, 4(1), 34 .

Li, H.; H. Kjerstadius, E. Tjernström and A. Davidsson. (2013). Evaluation of pretreatment methods for increased biogas production from macro algae. SGC Rapprot, 278.

Miranda, J. R.; P. C. Passarinho and L. Gouveia. (2012). Pre-treatment optimization of Scenedesmus obliquus microalga for bioethanol production. Bioresource technology, 104, 342-348.

Mtui, G. Y. S. (2009). Recent advances in pretreatment of lignocellulosic wastes and production of value added products. African Journal of Biotechnology, 8(8), 1398-1415.

Murphy, J. D.; B. Drosg, E. Allen, J. Jerney, A. Xia and C. Herrmann. (2015). A perspective on algal biogas (pp. 535). IEA Bioenergy.

Nielfa, A.; R. Cano and M. F. Polanco. (2011). Theoretical methane production generated by the co-digestion of organic fractionmunicipal solid waste and biological sludge. Biotechnology Reports. 2015; 5: 14-21. PMid: 28435805 PMCid: PMC5374264. DEStech Publications, Inc, 18, 60-68.

Ogbonna, J. C. (2011). Suitability of Nigerian Weather Conditions for Cultivation of Microalgae, Nigerian Journal of Biotechnology 22, 60-65.

Passos, F.; J. Garcia and I. Ferrer. (2013). Impact of Low Temperature Pretreatment on The Anaerobic Digestion of Microalgal Biomass. Bioresour Technol. 138, 79-86.

Perazzoli, S., Steinmetz, R. L. R., Mezzari, M. P., Nunes, E. O., and Swine, E. (2013). Biogas production from microalgae biomass, 2011-2014.

Phukan, M.; R. Chutia, B. Konwar and R. Kataki. (2011). Microalgae Chlorella as a potential bio-energy feedstock. Applied Energy 88(10): 3307-3312.

Saharan, B. S.; D. Sharma, R. Sahu, O. Sahin and A. Warren. (2013). Review article towards algal biofuel production: a concept of green bio energy development. Innovative Romanian Food Biotechnology, 12, 1-21.

Schenk P. M., Thomas-Hall S. R., Stephens E., Marx U. C., Mussgnug Posten JHC, Kruse $O$ and Ben Hankamer B (2008). Second Generation Biofuels: High-Efficiency Microalgae for Biodiesel Production. J. BioEnergy Res. 1(1): 20-43

Sheehan J.; T. Dunahay, J. Benemann and P. Roessler. (1998). A Look Back at the U.S. Department of Energy's Aquatic Species Program-Biodiesel from Algae. Report, U.S. Department of Energy's Office of Fuels Development, Colorado, United States.

Sialve, B.; N. Bernet and O. Bernard. (2009). Anaerobic digestion of microalgae as a necessary step to make microalgal biodiesel sustainable. Biotechnology Advances, 27(4), 409416.

Uggetti, E.; P. Fabiana, S. Maria, M. Garfı and I. Ferrer. (2016). Recent Achievements in the Production of Biogas from Microalgae. Waste Biomass Valor. 8 - 10.

Ukonu, C. U. (2011). Optimization of biogas production using combinations of saw dust and cow dung in a batch 
anaerobic digestion bioreactor. (Masters thesis, University of Nigeria Nsukka).

Wang, M.; E. Lee, M. P. Dilbeck, M. Liebelt, Q. Zhang and S. J. Ergas. (2017). Thermal pretreatment of microalgae for biomethane production: experimental studies, kinetics and energy analysis. Journal of Chemical Technology \& Biotechnology, 92(2), 399-407.

Zhang, Z.; W. Li and G. Zhang. (2014). Impact of pretreatment on solid state anaerobic digestion of yard waste for biogas production. World J Microbiol Biotechnol, 547554.

Zou, S.; Y. Wu, M. Yang, C. Li and J. Tong. (2010). Biooil production from sub- and supercritical water liquefaction of microalgae Dunaliella tertiolecta and related properties. Energy \& Environmental Science, 3(8), 1073. 